\title{
Structures of Teen-Lit Stories Written By Indonesian Teenage Authors
}

\author{
Agus Hari Wibowo \\ Universitas Sebelas Maret \\ Surakarta, Indonesia \\ agushari67@staff.uns.ac.id
}

\author{
Djatmika \\ Universitas Sebelas Maret \\ Surakarta, Indonesia \\ djatmika@staff.uns.ac.id
}

\begin{abstract}
This article talks about the exploitation of disourse units performed by Indonesian teenage writers in constructing teen-lit stories in bahasa Indonesia. Ten narrative texts in various genres were selected as the focus of discussion. They were analysed for types of discourse units selected by the authors to build up the story texts. Further, the analysis is also conducted to see the function of each discourse unit in such stories. The results show that the teenage authors are creative in constructing the narrative texts. Some of them are build up as novels, short stories, scary stories, and also comedy stories. Even though all the texts are narrative, each type show different discourse unit selection and construction. In addition, the authors are good to make creation for the discourse unit arrangement for their stories.
\end{abstract}

Keywords-text structure, stories, teenage, author, genre

\section{INTRODUCTION}

As young adult literature or teenlit has been growing and becoming new opportunities (Short, 2018), teenagers nowdays are showing their interest to share their writing to public. The desire of teenagers to express their literary works has been accommodated by several modes. They can publish their text in the form of printed books or in online websites. Kehus (2000) has been organizing a site of TeenLit.com to accommodate teenagers publish their works. This got a support by Anonymous (2000) who provided web sites for professional literacy accommodation. Most of writers who have joined this community tend to share their poetry and short stories. This phenomena also happens in Indonesia, in which several teenager writer communities open oportunities for any body to share her/ his writing composition mostly in the forms of fiction. Four short stories being the objects of analysis in this article were randomly taken from these sites.

Meanwhile, teenlit texts can represent the quality of language exploitation performed by the teenage writers. The way they select discourse units and construct them for narrative texts will show their strenght in undestanding stages of such texts as well as the function each unit has in a story text. As the content of such story texts will represent the condition of the teenage writers, then selection of discourse units and the arrangement of them should accommodate such a condition. Put in other words, teenlits seem to have special language exploitation to accommodate the features of the genre (VanderStaay, 1992). Related to this phenomena, teenagers tend to have special and different way of composing their narrative texts.

As one of text types, narrative text need discourse units for its structrure. Three of the units, namely orientation, complication and resolution must exist in one text, otherwise it fails to be narrative (Gerot \& Wignell, 1995; Santosa, Djatmika, \& Primasita, 2006; Djatmika, Khrisna, \& Nuraeni, 2012). Moreover, there are two different discourse units which might complete those obligatory one, i.e. evaluation and coda whose appearance in one narrative text is optional-the absence of these units in one text will not have any influence to such a text to be narrative. The common arrangement of the must-be-present discourse units is orientation-complicationresolution, while one optional unit, evaluation, is positioned preceding a resolutin and coda is at the end of a story. However, many writers tend to have their own style in constructing these units into a story text. They might have repeated pattern in which an orientation is followed by double or even multiple complication-resolution sequential arrangements. If evaluation must be present in these arrangement, its posititon is constant, i.e, before the resolution, while a coda is always at the end of the text.

\section{RESEARCH METHODS}

Ten narative texts for teenagers or commonly termed as teenlit were collected to be the focus of the research. They were analysed to the see the macro dan micro genre. The former was represented by the main discourse units the authors selected and designed for the main story, while the latter are related to the text structure of parts of the main story. Both will represent the quality and pattern of discourse unit arrangement for each narrative text.

\section{RESULTS}

Narratives are of several types, but whatever the type, a text in narrative genre will have three obligatory discourse unit, i.e. orientation, complication, and resolution. In addition to these units, a text might also have additional or optional discourse units, namely evaluation and coda. All stories in this study were selected as narrative. The authors of the stories design the texts in such a way so that they have social function as a narrative - that they will provide entertainment to the readers by telling something happening in the past in which problems or conflicts flow to a crisis and end in a resolution. 
The first 'text building' to see is the macro genre of the narrative texts. Based on the discourse units and their arrangement in the text, each text then has a macro genre confugaration as presented in the following table.

\section{TABLE I. MACRO GENRE OF TEENLITS}

\begin{tabular}{|l|c|c|c|c|}
\hline \multicolumn{1}{|c|}{ Title } & \multicolumn{2}{|c|}{ Types of Genre } & \multicolumn{2}{c|}{ Genre Format } \\
\hline & Novel & $\begin{array}{c}\text { Short } \\
\text { Story }\end{array}$ & Single & Repeated \\
\hline Tragedi (Asiza, 2003) & $\sqrt{ }$ & & & $\sqrt{ }$ \\
\hline $\begin{array}{l}\text { House of Lake (Faradina, } \\
\text { 2017) }\end{array}$ & $\sqrt{ }$ & & & $\sqrt{ }$ \\
\hline $\begin{array}{l}\text { Ghost } \\
\text { (Ramadhani, 2017) }\end{array}$ & $\sqrt{ }$ & & & $\sqrt{ }$ \\
\hline $\begin{array}{l}\text { BukanJilbabSemusim } \\
\text { (Teera, 2006) }\end{array}$ & $\sqrt{ }$ & & & $\sqrt{ }$ \\
\hline $\begin{array}{l}\text { Pulau Pemujaan Setan (Ha, } \\
\text { 2017) }\end{array}$ & $\sqrt{ }$ & & & $\sqrt{ }$ \\
\hline $\begin{array}{l}\text { Tidak Pernah Ada Kita } \\
\text { (Dwitasari, 2018) }\end{array}$ & $\sqrt{ }$ & & & $\sqrt{ }$ \\
\hline $\begin{array}{l}\text { Harapan Mati (Azzahra, } \\
\text { 2013) }\end{array}$ & & $\sqrt{ }$ & & $\sqrt{ }$ \\
\hline $\begin{array}{l}\text { Happy Ending (Ameliya, } \\
\text { 2013) }\end{array}$ & & $\sqrt{ }$ & & $\sqrt{ }$ \\
\hline $\begin{array}{l}\text { Kotak Musik (Pratiwi, } \\
\text { 2016) }\end{array}$ & & $\sqrt{ }$ & & $\sqrt{ }$ \\
\hline IX SMP (Hulu, 2017) & & $\sqrt{ }$ & & $\sqrt{ }$ \\
\hline
\end{tabular}

Related to macro genre, the table above presents general pattern of structure the narrative texts have eventhough they are of two types of text, i.e. novel and short story. All are constructed by three obligatory discourse units for narrative such as orientation, complication, and resolution. Meanwhile, the optional discourse unit, i.e. evaluation and coda tend to come up in novels than in short stories. Put in other words, novels have all discourse units as to construct them to be narrative, but not all of short stories have complete discourse units to be a narrative text.

As the novels are arranged in chapters, then the distribution of such discourse units for narrative above is represented in chapters. In sequential order, the orientation is accommodated by one chapter or two in the beginning part, and the following units will be presented in the following chapters. The ending chapter tends to be the closing part which accommodates the resolution as well as the coda if this optional unit comes up in a story. On the other hand short stories in this research show different arrangement for text structure. As the stories are much shorter than novels, they are not composed in chapters but in paragraphs. The discourse units of the short stories tend to be identified just from their functions in the story text. A part or a paragraph which introduces the participants and the setting of a story will be the orientation of a text, the other part presenting problem will be the complication, and the part which tells the solution of the problem becomes the resolution of such a story, and similar cases happen for evaluation and coda if they exist in such a text.
In association with the pattern of discourse unit arrangement, all narrative texts are built up in what so termed as repeated and no single text has a single discourse unit arrangement represented in an arrangement of orientationcomplication-(evaluation)-resolution-(coda) with optional units in brackets. Units that potentially happen several times in one text are complication and resolution. For novels, the authors tend to present multiple problems or conflicts in their stories, and units representing the solution for the problems/conflicts are arranged going after the problems/ conflicts. To accommodate such a style, then the teenage writers tend to format one chapter for a conflict followed by another for a resolution, then this pattern of arrangement is repeated for other conflict-resolution. The other style is shown by arranging two or more chapter for multiple rising conflict, then they are solved in one chapter as the climax of the story. The following table displays macro text structure of novels.

\section{TABLE II. CHAPTERS FOR DISCOURSE UNITS IN} NOVELS

\begin{tabular}{|l|c|c|c|c|c|}
\hline \multicolumn{1}{|c|}{ Title } & Orientation & Complication & Evaluation & Resolution & Coda \\
\hline Tragedi & 1 & $2-14$ & - & 15 & - \\
\hline $\begin{array}{l}\text { House of } \\
\text { Lake }\end{array}$ & 1 & $2-8$ & - & 9 & - \\
\hline $\begin{array}{l}\text { Ghost } \\
\text { Dormitory }\end{array}$ & 1 & $2-23$ & - & 24 & 24 \\
\hline $\begin{array}{l}\text { Bukan } \\
\text { Jilbab } \\
\text { Semusim }\end{array}$ & 1,3 & $2,4,5,6,7,8,9,10,11$ & - & 12 & - \\
\hline $\begin{array}{l}\text { Pulau } \\
\text { Pemujaan } \\
\text { Setan }\end{array}$ & 1,2 & $3-19$ & - & 20 & 21 \\
\hline $\begin{array}{l}\text { Tidak } \\
\text { Pernah } \\
\text { Ada Kita }\end{array}$ & 1 & $2,5,7$ & $3,6,8$ & 4,9 & 10 \\
\hline
\end{tabular}

Table II shows three novels having similar pattern of structure in which such novels are initiated by an orientation accommodated by chapter one. Unit complication is presented in chapter two to the one prior the last chapter which is designed for resolution. These novels do not have evaluation and coda for their optional units. Each of the remaining novels has different discourse units construction. A novel entitled Bukan Jilbab Semusim is built up with three obligatory units, and a coda as an optional one. The writer of such a novel presents the orientation in chapter one to introduce one of the main characters of the story, and the other introduction is skippingly designed for the other main character in chapter three. Unit of complication is in chapter 2, then it skips to chapter 4 to the chapter prior to the final one to present problems and conflict faced by character introduced in chapter one and the other presented in chapter two. Meanwhile, such problems and conflict between the main characters get solution in chapter 24-in the last part of the same chapter does the writer present the coda of the story.

The other novel entitled Pulau Pemujaan Setan needs two chapters to introduce the characters and the setting of the story. Similar to the previous stories, complication is accommodated by the following chapter, except chapter 20 
and 21 - the former presents the resolution, while the latter is for the coda of the story. Meanwhile, the last novel shows very different distribution compared to the others. It starts with orientation in chapter 1 . Following the introduction is an arrangement of complication-evaluation-resolution which is accommodated by chapter 2,3, and 4, while another construction of complication-evaluation-complicationevaluation-resolution is presented in chapter 5, 6, 7, 8, and 9 . The coda of the story is in the last chapter.

Meanwhile, each of the chapters that represent a unit of narrative text above has its own structure - and most of them is also constructed as narrative. It means that each chapter of the novels starts with an orientation, has complication and resolution, even it sometimes also has evalution and coda within the same chapter. The units with different functions in the chapter as a narrative are presented in paragraphs or sometimes part of paragraphs. This distribution is then similar to those happenning in short stories.

On the other hand, short stories show different discourse units exploitation. Due to their much shorter size, the structure units of short stories are represented by parts or paragraphs. One part or paragraph commonly represents one unit, but one unit can be accommodated by one or more parts/ paragraphs. The following table presents the distribution of parts or paragraphs for discourse units in short stories.

TABLE III. DISTRIBUTION OF PARTS/ PARAGRAPHS FOR DISCOURSE UNITS IN SHORT STORIES

\begin{tabular}{|l|c|c|c|c|c|c|c|c|c|c|c|c|}
\hline \multirow{2}{*}{ Title } & \multicolumn{10}{|c|}{ Function of Paragraph/ Part } \\
\cline { 2 - 15 } & 1 & 2 & 3 & 4 & 5 & 6 & 7 & 8 & 9 & 10 & 11 & 12 \\
\hline Harapan Mati & O & $\mathbf{O}$ & C/O & $\mathbf{C}$ & $\mathbf{C}$ & $\mathbf{C}$ & $\mathbf{C}$ & $\mathbf{C}$ & $\mathbf{C}$ & $\mathbf{R}$ & - & - \\
\hline Happy Ending & $\mathbf{O}$ & $\mathbf{C}$ & $\mathbf{C}$ & $\mathbf{E}$ & $\mathbf{R}$ & $\mathbf{C}$ & $\mathbf{C}$ & $\mathbf{C}$ & $\mathbf{C}$ & $\mathbf{E}$ & $\mathbf{R}$ & $\mathbf{C d}$ \\
\hline Kotak Musik & O/C & $\mathbf{C}$ & $\mathbf{C}$ & $\mathbf{C}$ & $\mathbf{C}$ & $\mathbf{C}$ & $\mathbf{R}$ & - & - & - & - & - \\
\hline IX SMP & $\mathbf{O}$ & $\mathbf{C}$ & $\mathbf{C}$ & $\mathbf{C} / \mathbf{R}$ & $\mathbf{C}$ & $\mathbf{C}$ & $\mathbf{C}$ & $\mathbf{C d}$ & - & - & - & - \\
\hline & & & & & & & & & & & & \\
\hline $\begin{array}{l}\text { C: Complication } \\
\text { Cd: Coda } \\
\text { E: Evaluation } \\
\text { O: Orientation } \\
\text { R: Resolution }\end{array}$ & & & & & & & & & & & & \\
& & & & & & & & & & & & \\
\hline
\end{tabular}

The above table shows that the each writer of the short stories exploit the text structure in different style. Most of them select three obligatory discourse units for a narrative, i.e. orientation, complication, and resolution, whereas one story is composed in complete discourse unit in which the writer also selects two optional discourse units, i.e. evaluation and coda in addition to the obligatory ones, and the other is written in three obligatory units and one optional one, i.e. coda.

All types of disourse units are distributed differently in each of the story. Most of parts or paragraphs of the texts represent one discourse unit or one function. However, each of three stories has one part with double functions. In this part/paragraph, the writer composed in such way that it has two discourse units in it. For example, in part/paragraph 3 in Harapan Mati, the writer created two functions. This part actually starts the complication unit, but in the end of such a part the writer introducing the main character of the story. Therefore, this paragraph is in one part a complication and the other an orientiation continuing paragraph one and two which have presented the introduction the setting of the story. The other cases happen in Kotak Musik in which one paragraph is partly an orientation and the other as complication, and in IX SMP in which a part has a double functions as complication and resolution.

On the other hand, one discourse unit in four short stories might be accommodated by single or multiple parts/ paragaphs. The table above shows, for example, that orientation is presented in part 1 , part 2 , and half of part 3, while complication starts at the end of part 3 and goes to part 9. Resolution is positioned after these complicating parts to end a story. The multiple parts for complication might suggest that the writer presents multiple conflicts or problems in these parts which then end in part 9 as the climax and part 10 is as the resolution as the falling climax. This pattern can be termed as single arrangment as the units of the texts are constructed in a simple flow of information-from orientation, complication andt resolution. Such a kind of arrangement also happens in Kotak Musik. Meanwhile, two other stories show different unit building. They are composed to have repeated pattern. The texts have two resolution units - it means that the pattern of orientationcomplication-resolution is repeated in the same texts. In addition, opitional unit (s) also complete the pattern.

One important phenomena related to the way the teenage authors construct their stories is strategy in presenting the flow of the stories. Discourse units for their stories are not only presented in narration, but also represented by dialogues of the characters. Put in other words, conversations or interactions between or among characters might represent certain units of the narrative structure. The other case that shows the writers skill in constructing units of such texts is that a story tends to have multiple problems or conflicts - this arrangement can represent rising complication which will end in a part in which a resolution - and sometimes a coda-is presented.

\section{CONCLUSION}

Ten texts-six novels and four short stories-are narrative as their macro genre. The distribution of discourse units both the obligatory and the optional ones are accommodated by chapters in the novels and by 
paragraphs or parts in the short stories. Within the macro structure, the novels have smaller units as chapters of the story books which are generally also composed as narrative. The stories structure quality indicates creativity of the teenages in selecting proper discourse units and in arranging them to be narrative texts of tennage style.

\section{References}

Ameliya, T. M. (2013). Happy Ending. Retreived from:https://www.lokerseni.web.id/2013/01/cerpenremaja-happy-ending.html

Anonymous. (2000). Web sites of interest to literacy professionals. Journal of Adolescent \& Adult Literacy, 44(3) 303

Asiza, F. (2003). Tragedi. Bandung: Mizan Media Utama.

Azzahra, Q. (2013). Harapan Mati. Retreived from: http://cerpenmu.com/cerpen-cinta-sedih/harapan-mati.html

Djatmika; Khrisna, D.A; \& Nuraeni, A. (2012). Systemic strategis to improve the readability of the English version of Indonesian children stories. KATA, 14(2).

Dwitasari. (2018). Tidak pernah ada kita. Jogjakarta: Bentang Belia.
Faradina, D. (2017). House of lake. Bandung: Mizan Media Utama

Gerot, L. \& Wignell, P. (1995).Making sense of functional grammar. Cammeray: AEE.

Ha, L. (2017). Pulau pemujaan setan. Jakarta: Grasindo.

Hulu, A.E. (2017). IX SMP. Retreived from: http://cerpenmu.com/cerpen-remaja/ix-smp.html

Kehus, M. .J. (2000). Opportunities for teenagers to shara their writing online. Journal of Adolescent \& Adult Literacy, 44(2) 130-137

Pratiwi, A. (2016). Kotak musik. Retreived from: http://shafiyyatul.com/news/2016/03/24/cerpen-karyasiswa-smp-maret-2016/

Ramadhani, S. (2017).Ghost dormitory. Bandung: Mizan Media Utama.

Santosa, R.,Djatmika \& Primasita, F.A. (2006).Sastra anak sebagai wahana pengenalan dan pengasuhan ideologi: Sebuah kajian wacana. Jurnal Penelitian Humaniora Special Edition.

Short, K. G. (2018). What's trending in children's literature and why it matters. Language Arts, 955 287-298

Teera.(2006). Bukan jilbab semusim. Solo: TigaSerangkai

VanderStaay, S. (1992). Young-adult literature: A Writer Strikes the Genre. English Journal, 81(4) 48-52 